\title{
Hydraulic lime mortars incorporating micro cork granules with antifungal properties
}

\author{
Alexandre Jerónimo ${ }^{a, *}$, Célia Soares ${ }^{b}$, Barroso Aguiar $^{\mathrm{a}}$, Nelson Lima ${ }^{\mathrm{b}}$ \\ a Departamento de Engenharia Civil, Universidade do Minho, Campus de Azurém, 4800-058 Guimarães, Portugal \\ ${ }^{\mathrm{b}}$ CEB- Centre of Biological Engineering, Micoteca da Universidade do Minho, Universidade do Minho, Campus de Gualtar, $4700-320$ Braga, Portugal
}

\section{H I G H L I G H T S}

- Antifungal properties could be found in the sample with $2 \%$ of cork.

- It is a potential starting point for transition from current to new antifungal protections.

- It will allow an improvement of users health and constructions and environmental quality.

- Despite the reduction in physical performance, mortars obtained CSII classification.

\section{A R T I C L E I N F O}

Article history:

Received 21 December 2019

Received in revised form 22 April 2020

Accepted 25 April 2020

\section{Keywords:}

Sustainability

Fungi

Porosity

Circular economy

\begin{abstract}
A B S T R A C T
This study aimed to develop a mortar based on hydraulic lime and micro cork granules with antifungal properties. For this purpose, five different compositions were developed, where the amount of cork granules was different and physical and mechanical characterisations were performed. It was observed that the incorporation of micro cork granules causes significant differences in properties such as workability, compressive strength and flexural strength. Some changes in mortars were circumvented by varying the dosage of superplasticizer. The antifungal properties of micro cork granules - added mortars were observed. The results obtained can be considered as a starting point for a transition from current antifungal protections to a new antifungal technique using cork industrial waste materials.
\end{abstract}

(c) 2020 Elsevier Ltd. All rights reserved.

\section{Introduction}

According to the Portuguese Cork Association, Portugal in 2015 was the leading cork producer with $49 \%$ of world production. From these, $25 \%$ of its exports are used in construction and decoration materials [1]. This interest is due to the cork properties: high resistance to abrasion, non-toxicity, hypoallergenicity, elasticity, compressibility, thermic, acoustic, viscoelasticity and nonpermeability to gases and liquids [2,3]. Cork is also recyclable and biodegradable which in the current world context contributes for a more sustainable and ecological construction [4]. Annually the world cork industry processes more than 280,000 tons of cork, however about $25 \%$ of the raw material is rejected, mainly as cork dust [5]. At all stages of the industrial process cork dust with fragments between 10 and $500 \mu \mathrm{m}$ and a very small fraction of

\footnotetext{
* Corresponding author at: Departamento de Engenharia Civil, Universidade do Minho, Campus de Azurém, 4800-058 Guimarães, Portugal.

E-mail addresses: ajaj@sapo.pt (A. Jerónimo), celia.soares@ceb.uminho.pt (C. Soares), aguiar@civil.uminho.pt (B. Aguiar), nelson@ie.uminho.pt (N. Lima).
}

micrometre minerals is generated [6,7]. At present, the cork industry takes advantage of these residues, mainly through direct energy recovery and biomass as a renewable energy source seems to be a promising option for improving the environmental situation [8,9], but there are no elements and data on the overall impacts that these end-wastes generate [10].

Other industries have been developing methods for the reutilization of cork dust to add-value to this by-product and be closer to the circular economy paradigm. The antioxidant capacity presented by some existing compounds in cork has attracted the pharmaceutical industry which considers promising the development of new pharmaceutical therapies that may be less expensive and/or less toxic than synthetic compounds [11]. Other examples are the sorption material developed for the removal of pharmaceuticals from aqueous solutions and the use of cork as antimicrobial material [12-14]. The potential antimicrobial capacity of cork is relevant in the area of construction. Microorganism contamination on the surface of mortar and concrete is recurrent despite the high alkalinity of these materials. The development of microorganisms such as bacteria and fungi is due to the neutralization (or carbon- 
ation) process of the materials when exposed to humidity for a prolonged period of time [15]. The prevention of fungal growth has been effective using fungicidal admixtures in the casting stage of mortar and concrete [16,17], however, these antifungal products can be washed out to the environment jeopardizing the fungi diversity.

The use of a bioproduct such as cork with focus in the sustainability of the planet has created the need to search for the development of new methods to meet this demand. With this in mind, the main aim of the present work was to develop micro cork granules mortars with antifungal capacity to use in construction that might lead to the creation of a new type of cementous composites.

\section{Materials and methods}

\subsection{Materials}

To perform this study, the following materials were used: 1) a binder of hydraulic lime (NHL5), with a density of $1400 \mathrm{~kg} / \mathrm{m}^{3}$ and particles size $<200 \mu \mathrm{m}$; 2) river sand, with a density of $2569 \mathrm{~kg} / \mathrm{m}^{3}$ and mean particle size of $0.762 \mathrm{~mm}$; 3) superplasticizer (SP) based on polyacrylate, with a density of $1050 \mathrm{~kg} / \mathrm{m}^{3}$; 4) the micro cork granules MF8, with a density of $300 \mathrm{~kg} / \mathrm{m}^{3}$ and mean diameter of $51.75 \mu \mathrm{m}$. The micro cork sample analysis obtained by laser diffraction (LD) showed granulometric values of: $\mathrm{D}[4.3]=56.51 \mu \mathrm{m}, \mathrm{D}[3.2]=40.21 \mu \mathrm{m}, \mathrm{D}[90]=98.54 \mu \mathrm{m}$ and $\mathrm{D}[10]=23.79 \mu \mathrm{m}$. In Fig. 1 we can see the image Energy dispersion X-ray spectroscopy (EDS) of the micro cork granules sample in (+) point and in table 1 its chemical characterization

\subsection{Composition and fabrication}

Five distinct formulations of mortars were developed (Table 2) with different percentages of micro cork granules (2, 4, 6 and 8\%). A $\mathrm{B} 0$ reference composition, i.e., no addition of micro cork granules, was used as control. Specimens used for the determination of compressive and flexural strength were mixed and manufactured according to EN 1015-11 [18]. For each studied composition, three prismatic specimens were moulded with dimensions of $40 \times 40 \times 160 \mathrm{~mm}^{3}$.

\subsection{Methods for lime mortar characterisation}

Workability test of the hydraulic lime mortars was performed following the guidelines of the European standard EN 1015-3

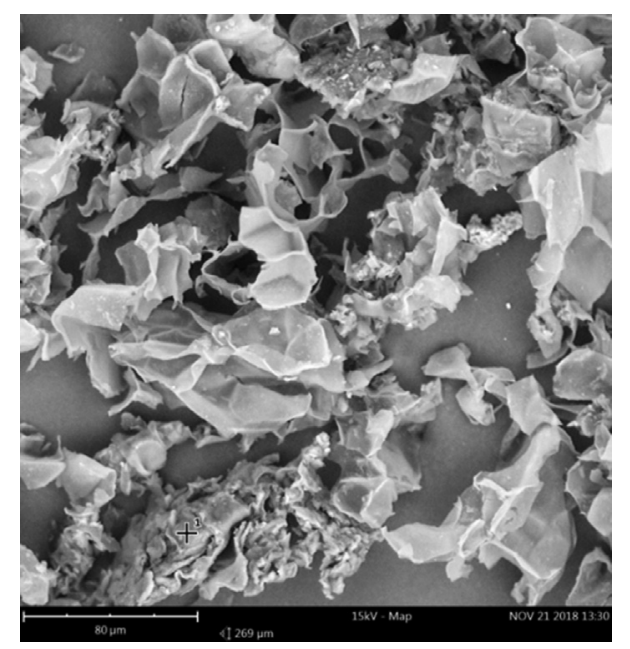

Fig. 1. Energy dispersion X-ray spectroscopy (EDS) of the micro cork granules sample in $(+)$ point.
[19]. Pore size and distribution were analysed by intrusion of mercury and helium gas using the Mercury Intrusion Porosimetry (MIP) instrument (Quantachrome, Florida, USA). The pressure used ranged between 0.2396 and $413 \mathrm{MPa}$ and allowed the measurement of the pore size from $10.64 \mu \mathrm{m}$ to $3.5 \mathrm{~nm}$. In the analysis, an advanced/retreating contact angle of mercury of $140^{\circ}$ and a surface tension of $0.480 \mathrm{~N} / \mathrm{m}$ were used. The specimens were cured in the laboratory at room temperature, hermetically sealed up to 28 days. The evaluation of resistance to the flexion and compression was made based on the European standard EN 1015-11 [18]. For the flexural strength 15 samples ( 3 per mortar) were used and for the compression strength 30 samples ( 6 per mortar) were used. For flexural behaviour, samples were tested as described by Jerónimo et al. [20].

\subsection{Fungal isolation and identification}

Twelve samples from walls and ceilings of different construction sites were collected for the isolation of fungi. The sampled material was plated directly in Dichloran Rose Bengal Chloramphenicol Agar (DRBC agar, Oxoid, Altrincham, UK) and incubated for 3-5 days. Considering the low water activity of the samples, the isolation was directed to specific filamentous fungi known to grow in these structures [21]. The isolates were transferred to Potato Dextrose Agar (PDA, Oxoid) and maintained for further studies. Morphological identification was performed by preparing slides for light optical microscopic observations using tissue removed from 7 day old colonies grown on PDA and mounted in lactophenol cotton blue. Morphologies were observed using an optical microscope (Leica DM5000B, Germany). For the assay purpose a single isolate was submitted to molecular biology. DNA extraction was performed using a "FastDNA ${ }^{\circledR}$ SPIN Kit" (MP Biomedicals, Santa Ana, USA) according to the manufacturer's handbook. Gene amplification of beta tubulin gene (BenA) was performed using the method described in Ouhibi et al. [22]. The fungal isolate chosen to perform the antifungal assay was deposited in Micoteca da Universidade do Minho (MUM) culture collection with the unique number strain MUM 19.43.

\subsection{Accelerated fungal growth}

For accelerated fungal growth brick samples were prepared according to [20]. After 28 days in the laboratory all samples, except one to be used as negative control, were sprayed with a spore solution of approximately $3 \times 10^{5}$ conidia $/ \mathrm{cm}^{2}$. The samples were placed in a climate chamber with constant relative humidity of $85 \%$ at $25{ }^{\circ} \mathrm{C}$. Three plates with Malt Extract Agar (MEA: malt extract $20 \mathrm{~g} / \mathrm{L}$; mycological peptone $1 \mathrm{~g} / \mathrm{L}$; glucose $20 \mathrm{~g} / \mathrm{L}$; agar, $15 \mathrm{~g} / \mathrm{L}$ ) were placed in the chamber as positive test and sprayed. To further accelerate the growth of the fungal isolate one of the samples was sprayed with Malt Extract Broth (MEB: malt extract $20 \mathrm{~g} / \mathrm{L}$; mycological peptone $1 \mathrm{~g} / \mathrm{L}$; glucose $20 \mathrm{~g} / \mathrm{L}$ ) as a nutritional source for the fungal development. For this, an area of $10 \mathrm{~cm}^{2}$ of the samples was selected and sprayed with $4.2 \mathrm{~mL}$ of MEB. The assay in the climate chamber (Relative humidity, RH 85\%) lasted 49 days and the samples were then observed by scanning electronic microscopy (SEM).

\subsection{Scanning electron microscopy}

Samples were characterized using a desktop Scanning Electron Microscope (SEM) (Phenom ProX, Netherlands). All results were acquired using the ProSuite software v.3.0. Non-conductive and uncoated samples were added to aluminium pin stubs with electrically conductive carbon adhesive tape (PELCO Tabs ${ }^{\mathrm{TM}}$ ) on a Phenom Charge Reduction Holder (CRH) at $5 \mathrm{Kv}$ and a spot size of 3.3. 
Table 1

Chemical identification of the cork sample at the $(+)$ point.

\begin{tabular}{|c|c|c|c|c|}
\hline Element $\mathrm{n}^{\circ}$ & Symbol & Name & Atomic concentration (\%) & Weight (\%) \\
\hline 6 & $\mathrm{C}$ & Carbon & 77.36 & 71.48 \\
\hline 8 & 0 & Oxygen & 22.25 & 27.39 \\
\hline 19 & $\mathrm{~K}$ & Potassium & 0.24 & 0.71 \\
\hline 17 & $\mathrm{Cl}$ & Clorine & 0.08 & 0.23 \\
\hline 20 & $\mathrm{Ca}$ & Calcium & 0.05 & 0.14 \\
\hline 15 & $\mathrm{P}$ & Phosphor & 0.02 & 0.05 \\
\hline
\end{tabular}

Table 2

Formulation of mortars $\left(\mathrm{kg} / \mathrm{m}^{3}\right)$ used during the present study.

\begin{tabular}{|c|c|c|c|c|c|}
\hline Sample & Binder & Sand & SP & Cork & Water \\
\hline $\mathrm{B}_{0 \% \text { cork }}$ & 500.00 & 1407.52 & 1.00 & 0.00 & 292.56 \\
\hline $\mathrm{B} 1_{2 \% \text { cork }}$ & 500.00 & 1316.24 & 1.50 & 10.00 & 292.56 \\
\hline $\mathrm{B} 2{ }_{4 \% \text { cork }}$ & 500.00 & 1224.95 & 2.00 & 20.00 & 292.56 \\
\hline B3 $3_{6 \%}$ cork & 500.00 & 1133.67 & 2.50 & 30.00 & 292.56 \\
\hline B $4_{8 \% \text { cork }}$ & 500.00 & 1042.38 & 3.00 & 40.00 & 292.56 \\
\hline
\end{tabular}

SP- superplasticizer.

\section{Results and discussion}

\subsection{Workability}

Workability tests, important for the handling of the developed mortars, were realized based on the method of the table of spreading, specified by the European standard EN 1015-3 [19]. The resulting test values were only considered for values between 160 and $180 \mathrm{~mm}$. With increasing percentage of micro cork granules, the workability of the mortar decreased due to the granules fineness. Ramos et al. [23] had the same result for mortars with different percentage of cork ash. In order to keep the workability within the defined values it was used a SP. Thus, in Fig. 2 we can positively correlate $\left(r^{2}=1\right)$ the percentage of SP with the percentage of micro cork granules. Fig. 3 shows the change in samples weight with the increase of the cork aggregate.

\subsection{Porosimetry}

In Fig. 4, it is observed that in sample B3 with $6 \%$ cork the largest percentage of pores is between diameters 1 and $10 \mu \mathrm{m}$ (60\%) and $40 \%$ of the pores are smaller. In samples $\mathrm{B}_{0 \%}$ cork and $\mathrm{B} 4_{8 \%}$ cork the smallest percentage of pores is between diameters 1 and $10 \mu \mathrm{m}(30 \%)$ and $70 \%$ of the pores are smaller. In sample $\mathrm{B} 2_{4 \%}$ cork, $100 \%$ of the pores are between diameters 1 and $10 \mu \mathrm{m}$

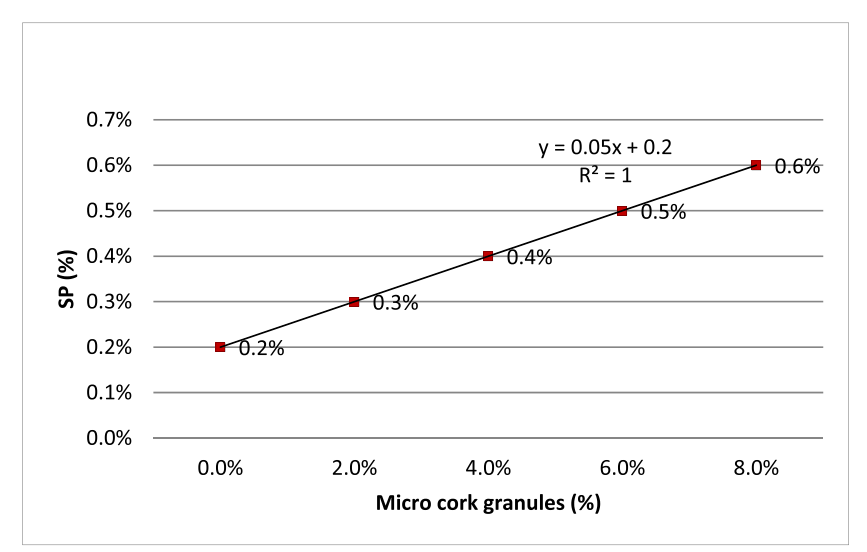

Fig. 2. Percentage of superplasticizer as a function of the percentage of micro cork granules.

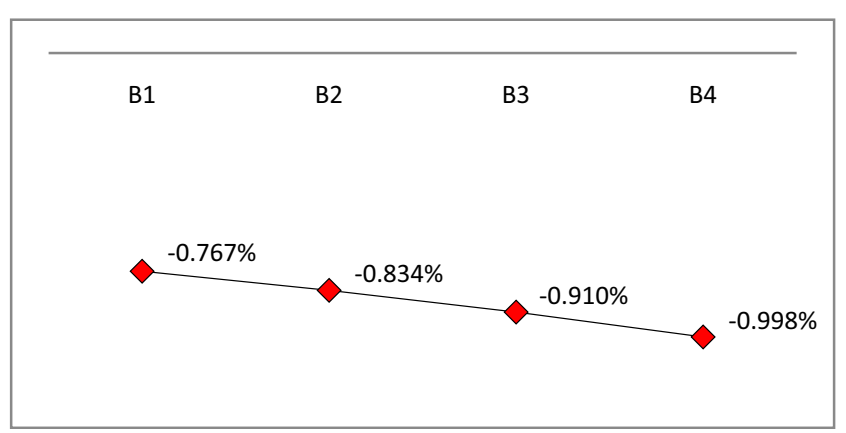

Fig. 3. Weigh variation in relation to sample B0.

and in sample $\mathrm{B} 1_{2 \% \text { cork }}$ the smallest percentage of pores is between diameters 1 and $10 \mu \mathrm{m}(2.5 \%)$ and $97.5 \%$ of pores are smaller. In Fig. 5 we verified that the majority of the samples under study have the amounts of larger pores between 2 and $3 \mu \mathrm{m}$ in diameter and smaller pores between 0.1 and $1 \mu \mathrm{m}$. However, there was an evident difference in the pore size evolution which might be explained by the manual mixing of the micro cork within the mortar. Using a different methodology such as water dispersion of the particles might improve the homogeneity.

Previous studies that have tested the addition of expanded cork granules to mortars [24,25] concluded that the expanded cork has an impact on the properties of the mortars, increasing their porosity through the cork granules expansion. However, there is not much information about the addition of micro cork granules. The use of these micro particles decreases the percentage of larger pores but as seen in Fig. 5, it is also observed that the growing introduction of micro cork granules increases the percentage of smaller pores with 0.1 to $1 \mu \mathrm{m}$ in diameter.

The total porosity of the samples acquired by MIP (Fig. 6) was obtained by the sum of the total interparticle porosity (porosity between particles) and the total intraparticle porosity (porosity within individual particles). With $\mathrm{BO}_{0 \%}$ cork as reference we expected that, with the increase of micro cork concentrations and subsequent filling of the gaps between bigger particles, the total porosity would decrease. With the first addition of micro cork in sample $\mathrm{B} 1_{2 \%}$ cork the interparticle porosity decreased but the intraparticle, due to the natural cork porosity, increased given a value slightly higher than in sample $\mathrm{BO}_{0 \%}$ cork. From this value the

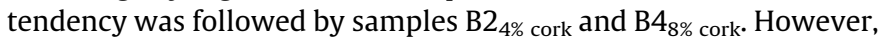
we observed that sample $\mathrm{B} 3_{6 \%}$ cork did not followed the trend. 


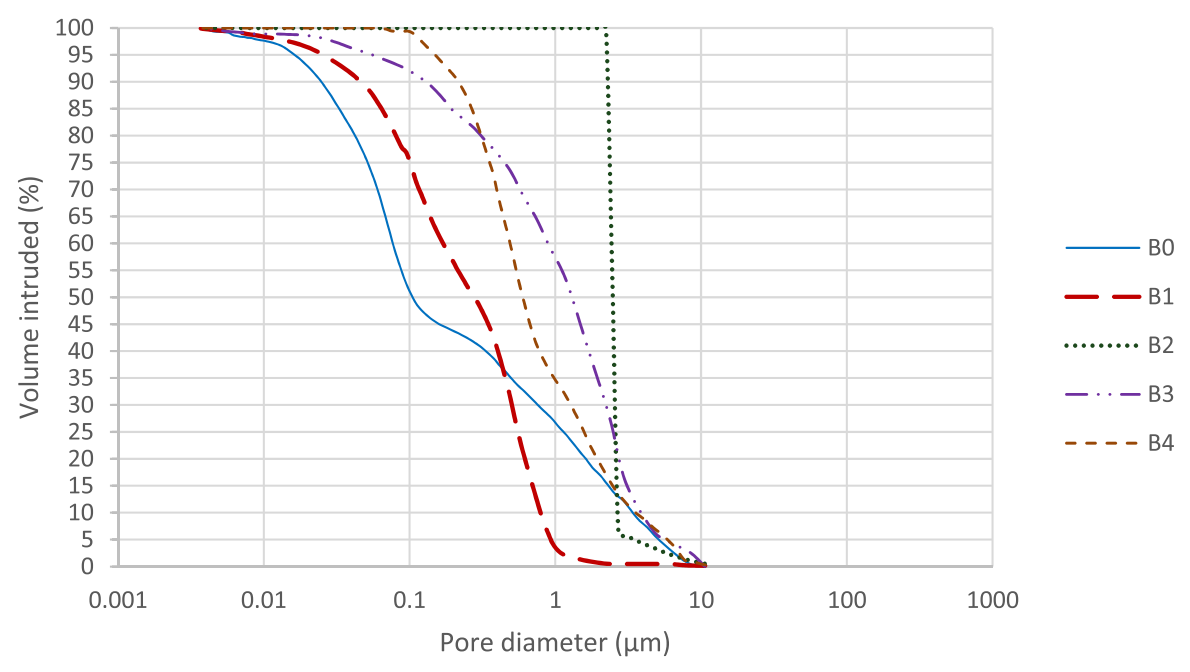

Fig. 4. Percentage of mercury increased in mortars at 180 days.

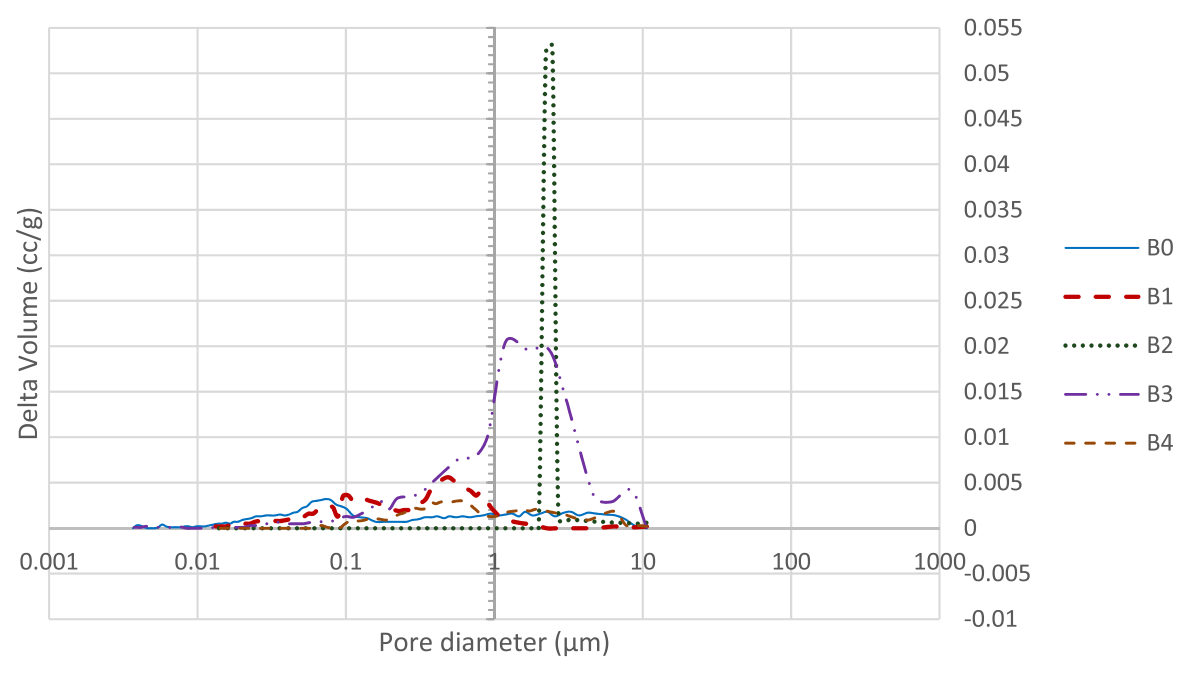

Fig. 5. Amount of mercury increased in mortars at 180 days.

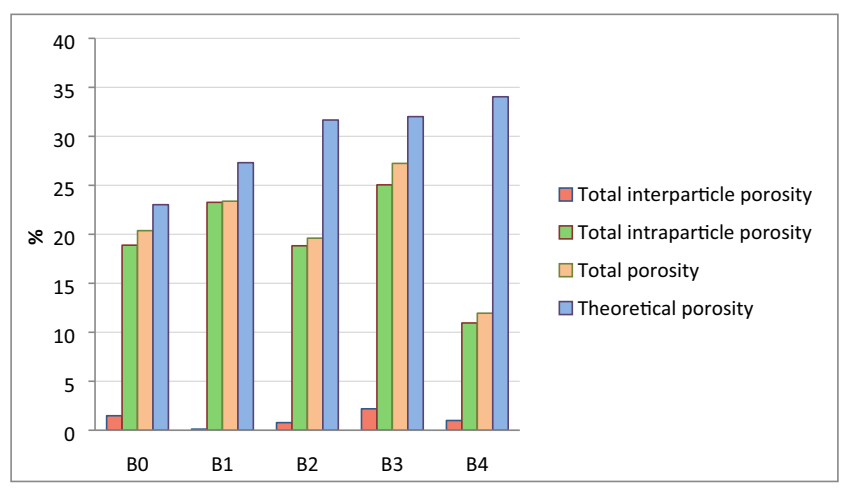

Fig. 6. Porosity of mortar at 180 days.

During the assays it was clear that with the manual incorporation of higher concentrations of these particles, as it would be done in a construction site, samples homogeneity was not easily achieved due to the increase in fine particles and their difficulty in mixing in the mortar. $\mathrm{B}_{0 \%}$ cork and $\mathrm{B} 1_{2 \%}$ cork samples had a very close pore structure and overall we can say that they were much less porous than $B 2_{4 \% \text { cork }}$ and $B 3_{6 \%}$ cork samples.

The values of theoretical porosity (obtained by helium porosimetry) were much higher in all samples (Table 3 ). This result was also obtained by Zhao et al [26] and explained due to the smaller molecule size of helium allowing this gas to reach previously inaccessible pores. As the theoretical porosity increases, the mortar is more homogeneous because the interparticle porosity is very low.

\subsection{Flexural and compression behaviour}

The reduced strength of cork ash mortars and the strength loss is greater with increasing percentage replacement has already been studied [23]. According to Fig. 7, it was possible to observe that with the incorporation of micro cork granules there was a decrease in compressive strength. There is also a decrease in flexural strength (Fig. 8), which is justified by the theoretical increase 
Table 3

Results of porosity of mortar at 180 days.

\begin{tabular}{|c|c|c|c|c|c|}
\hline Sample & Average porosity diameter (nm) & Interparticle porosity (\%) & Intraparticle porosity (\%) & Total Porosity (\%) & Theoretical porosity (\%) \\
\hline $\mathrm{BO}_{0 \% \text { cork }}$ & 58.20 & 1.48 & 18.89 & 20.37 & 23.02 \\
\hline $\mathrm{B} 1_{2 \% \text { cork }}$ & 91.74 & 0.12 & 23.26 & 23.38 & 27.31 \\
\hline $\mathrm{B} 24 \%$ cork & 25.10 & 0.78 & 18.83 & 19.61 & 31.66 \\
\hline $\mathrm{B} 36 \%$ cork & 196.90 & 2.19 & 25.05 & 27.24 & 32.01 \\
\hline $\mathrm{B} 4_{8 \% \text { cork }}$ & 458.70 & 1.00 & 10.95 & 11.95 & 34.04 \\
\hline
\end{tabular}

in porosity. It is also noted that despite the decrease in resistance $\mathrm{B} 1_{2 \% \text { cork }}$ and $\mathrm{B} 2_{4 \% \text { cork }}$ mortars, additive with micro cork granules, still have compressive strengths of 3.03 and $1.78 \mathrm{MPa}$, respectively.

In accordance with EN 998-1 [27], we can classify the mortars according to their compressive strength, which ranges between CSI (04 to $2.5 \mathrm{MPa}$ ) and CSIV ( $\geq 6.0 \mathrm{MPa}$ ). On Table 4 we can see that the incorporation of micro cork granules decreased the compressive strength of mortars and only $\mathrm{B} 1_{2 \%}$ cork and $\mathrm{B} 2_{4 \%}$ cork mortars are classified as CSII (1.5 to $5.0 \mathrm{MPa}$ ). The decrease of the compressive strength with the addition of materials to the mortars is not uncommon and is very material dependent. Cunha et al [28] had a similar result with the incorporation of phase change materials (PCM). In this case when we supplemented the mortars with micro cork granules it was found that the intraparticle porosity increased which shows the difficulty in mixing fine particles. Although the main objective of this study was to focus on the antifungal properties of the mortars, it was possible to verify that, despite the physical properties results, they were still in the applicability zone, which is a very positive factor.

\subsection{Fungal isolation and identification}

It was possible to isolate 15 filamentous fungi which were morphologically identified as belonging to 5 different genera (Alternaria, Aspergillus, Cladosporium, Penicillium, Stachybotrys). The isolate MUM 19.43 was molecularly identified as Cladosporium halotolerans and the BenA sequence was deposited on the GenBank under the accession number MN839644. In a review Verdier [29] stated that, with the exception of Alternaria, these are the most frequently isolated genera regardless of the technique, the environmental condition or the type of material. The criteria to choose the Cladosporium strain for the assay was related to the fact that is a common environmental species, produces a high amount of spores and has a potential effect in human health when growing indoors [30].

\subsection{Accelerated fungal growth}

The optimal conditions inside the climate chamber for the fungal development was confirmed after 3 days where visible growth

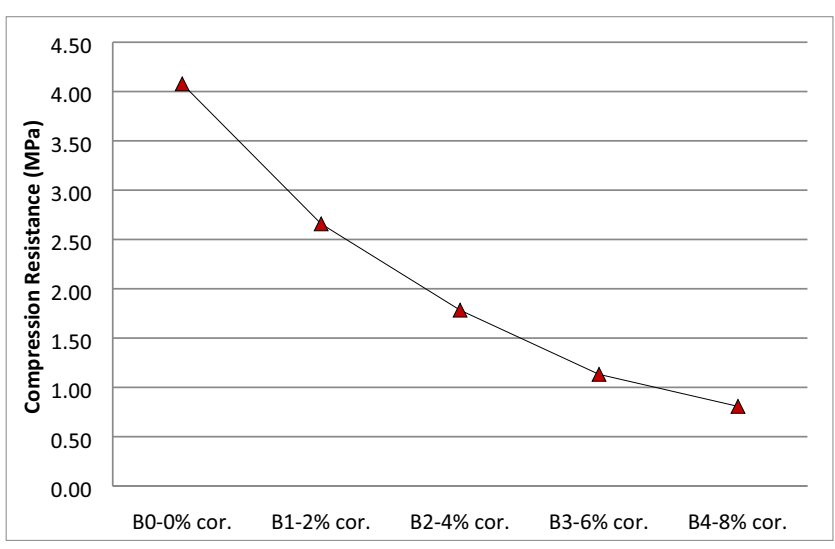

Fig. 7. Compressive behaviour of mortar at 28 days.

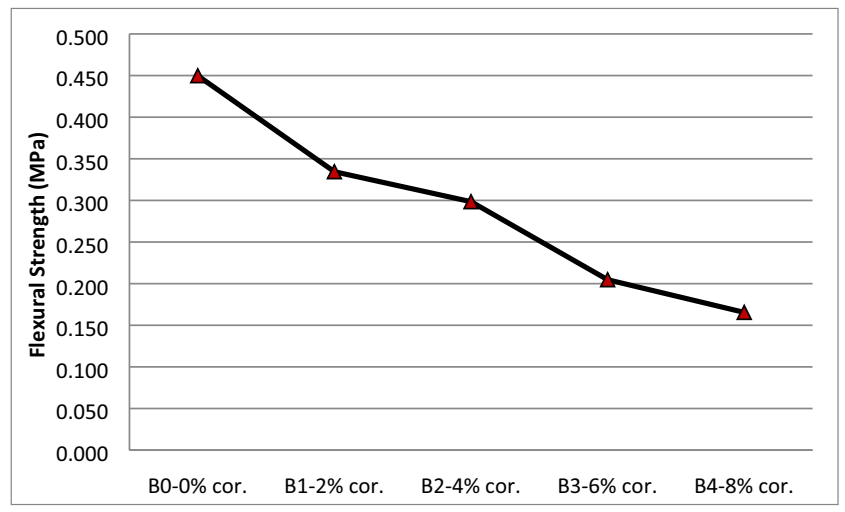

Fig. 8. Flexural behaviour of mortar at 28 days.

Table 4

Classification of mortars according to the compressive strength.

\begin{tabular}{lll}
\hline Sample & Compressive strength $(\mathrm{MPa})$ & Classification \\
\hline $\mathrm{B}_{0 \%}$ cork & 4.08 & CSII \\
$\mathrm{B} 1_{2 \%}$ cork & 3.03 & CSII \\
$\mathrm{B} 2_{4 \% \text { cork }}$ & 1.78 & CSII \\
$\mathrm{B} 3_{6 \%}$ cork & 1.13 & CSI \\
$\mathrm{B} 4_{8 \%}$ cork & 0.81 & CSI \\
\hline
\end{tabular}

in the MEA plates was observed. There are many factors that influence the fungal growth, such as water, oxygen and nutrients [30]. The RH $85 \%$ of the climate chamber allowed the fungi to have all the conditions to grow. Fig. 9 shows the evolution of the strain MUM 19.43 growth in all samples at a $3000 \times$ magnification. In the sample $\mathrm{B}_{0 \% \text { cork }}$, we found that the fungal mycelium was practically spread over the sample area, in sample B $2_{4 \%}$ cork there was more than $50 \%$ of the surface occupied by the strain. In samples $\mathrm{B} 3_{6 \%}$ cork and $\mathrm{B} 4_{8 \%}$ cork the $C$. halotolerans developed more easily and in sample $B 1_{2 \%}$ cork the strain was poorly developed. Similarly, to further accelerate the growth of the strain of $C$. halotolerans, during the 49 days essay, a sample was sprayed with MEB as a nutritional source for the fungal development. In the sample

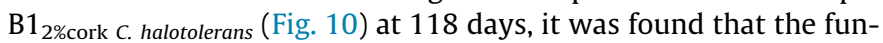
gal development remained low. Previous studies with different micro additives showed that there was significantly improvement of the antifungal properties of mortars [22,31] but this fact could only be observed in the sample $\mathrm{B} 1_{2 \%}$ cork.

According to Stanaszek-Tomal [32] pores can form a pore space in the material which can be filled with air, water and other substances that will promote the fungal development. Similarly, Hoang et al [33] referred that in contact with humidity porous materials can become supplies of water for microorganisms promoting their growth. The reason why only sample $\mathrm{B} 1_{2 \%}$ cork was able to prevent fungal growth may be related to the decrease of the interparticle porosity, which was the lowest measured in all samples, reducing the area for hyphal expansion and also the retention of essential air and water. 
B0
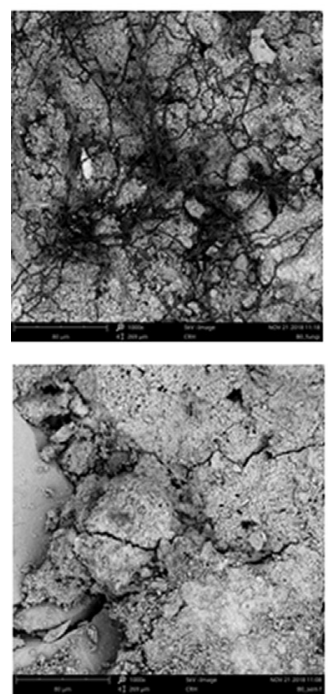

B1
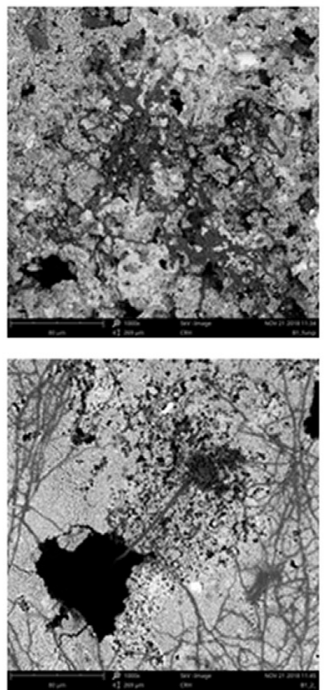

B2
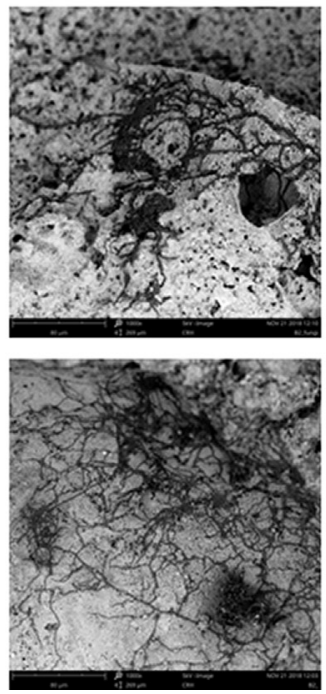

B3
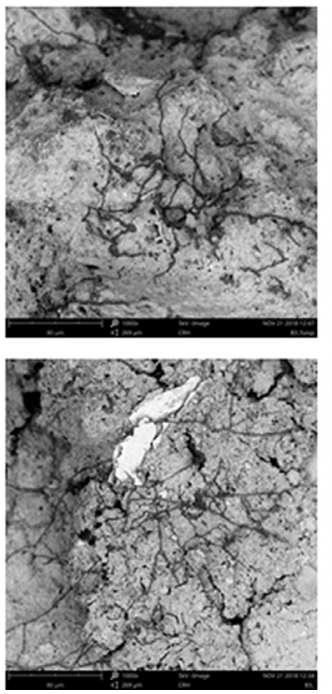

B4

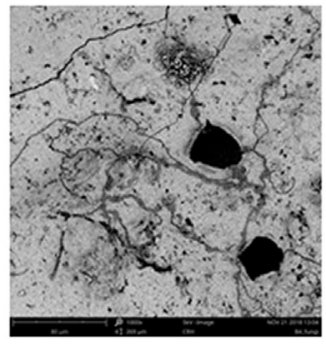

0
20
2
0
0
0
0
$\frac{1}{5}$
$\vdots 3$

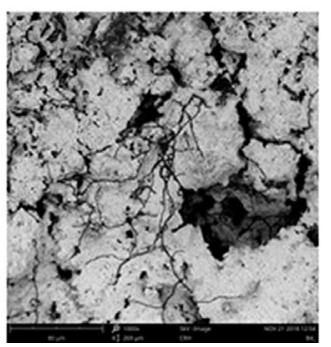

Fig. 9. Images of the samples viewed under the scanning electron microscope at 49 days (SEM $-3000 \times$ magnification).

B0

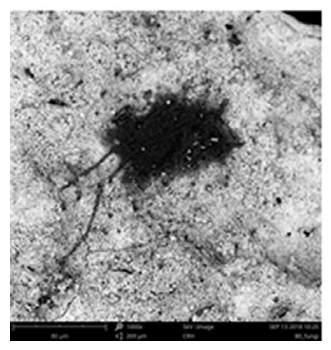

B1

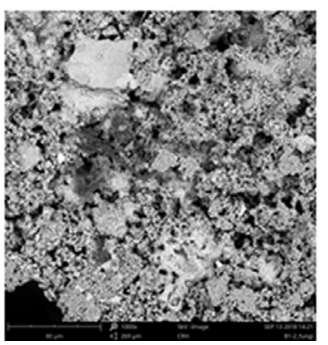

B2

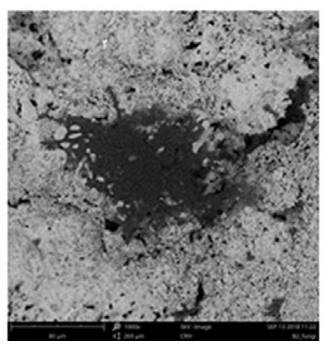

B3

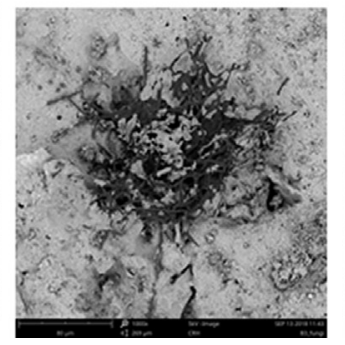

B4

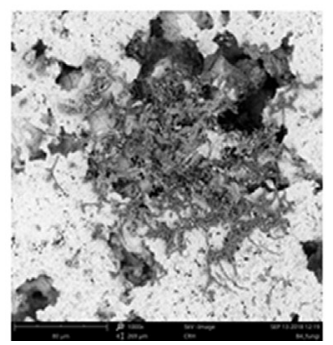

Fig. 10. Development of the C. halotolerans (MUM 19.43) viewed under the scanning electron microscope at 118 days (1000× magnification).

\section{Conclusions}

The work analysed the physical properties as well as the antifungal properties of the mortars with micro cork granules. The following conclusions may be formulated:

- The addition of micro cork granules reduces the physical performance and for values above $2 \%$ there was an increase in the theoretical porosity of the mortars;

- Although impairing the compressive strength of mortars, the samples $\mathrm{B} 1_{2 \%}$ cork and $\mathrm{B} 2_{4 \%}$ cork mortars reached the classification CSII;

- The increase of intraparticle porosity shows the difficulty in mixing fine particles;

- The decreased interparticle porosity may explain the best antifungal performance found in the $\mathrm{B} 1_{2 \%}$ cork sample at both 49 days and 118 days as well as the best physical and mechanical performances;

This study intends to contribute to the development of sustainable antifungal mortars, with good balance between physical and mechanical behaviour, fulfilling the application demands. In addition, this study opens the opportunity to add-value to the byproduct micro cork granules contributing to foster the circular economy approach.

\section{CRediT authorship contribution statement}

Alexandre Jerónimo: Conceptualization, Investigation, Methodology, Visualization, Project administration, Writing - original draft, Writing - review \& editing. Célia Soares: Methodology, Formal analysis, Writing - review \& editing. Barroso Aguiar: Supervision, Validation, Funding acquisition. Nelson Lima: Supervision, Validation, Funding acquisition.

\section{Declaration of Competing Interest}

The authors declare that they have no known competing financial interests or personal relationships that could have appeared to influence the work reported in this paper.

\section{Acknowledgments}

This research was supported by the Portuguese Foundation for Science and Technology (FCT) under the scope of the strategic funding of UIDB/04469/2020 unit and BioTecNorte operation (NORTE-01-0145-FEDER-000004) funded by the European Regional Development Fund under the scope of Norte2020 - Programa Operacional Regional do Norte. 


\section{References}

[1] APCOR, Estudo de caracterização sectorial - Cortiça. Estatísticas e prospetiva. CEGEA - Centro de Estudos de Gestão e Economia Aplicada, Universidade Católica Portuguesa, 2015 [in portuguese].

[2] L. Gil, Cortiça: produção, tecnologia e aplicação, INETI, Lisbon, 1998 [in portuguese].

[3] S.P. Silva, M.A. Sabino, E.M. Fernandes, Cork: Properties, capabilities and applications, Int. Mater. Rev. 50 (2005) 345-365.

[4] M. Urbaniak, R. Goluch-Goreczna, A.K. Bledzki, Natural cork agglomerate as an ecological alternative in constructional sandwich composites, BioResources 12 (2017) 5512-5524, https://doi.org/10.15376/biores.12.3: 5512-5524.

[5] SECIL, Argamassas com agregados de cortiça - Ficha técnica, SECIL, 2011 (in portuguese).

[6] A.M. Matos, S. Nunes, J. Sousa-Coutinho, Cork waste in cement based materials, Mater. Design 85 (2015) 230-239, https://doi.org/10.1016/j.matdes. 2015.06.082.

[7] B. Valentim R. Rocha A. Guedes Quercus suber cork and respective fly ash characterization by FEG-ESEM/EDS 2015 Porto

[8] L.J.R. Nunes, J.C.O. Matias, J.P.S. Catalão, Energy recovery from cork industrial waste: Production and characterisation of cork pellets, Fuel 113 (2013) 24-30 https://doi.org/10.1016/j.fuel.2013.05.052.

[9] F.J. Sepúlveda, J.I. Arranz, M.T. Miranda, I. Montero, C.V. Rojas, Drying and pelletizing analysis of waste from cork granulated industry, Energies 11 (2018) 109, https://doi.org/10.3390/en11010109.

[10] S.V. Vassilev, D. Baxter, L.K. Andersen, C.G. Vassileva, An overview of the chemical composition of biomass, Fuel 89 (2010) 913-933.

[11] S.T.D.O. Mendes, Desenvolvimento de formas farmacêuticas de ação tópica, Universidade de Coimbra, Coimbra, 2013 [in portuguese].

[12] A.V. Dordio, P. Gonçalves, D. Teixeira, A.J. Candeias, J.E. Castanheiro, A.P. Pinto, A.J.P. Carvalho, Pharmaceuticals sorption behaviour in granulated cork for the selection of a support matrix for a constructed wetlands system, Int. J. Environ. An. Ch. 91 (2011) 615-631, https://doi.org/10.1080/03067319.2010.510605.

[13] N.R. Neng, A.S. Mestre, A.P. Carvalho, J.M.F. Nogueira, Cork-based activated carbons as supported adsorbent materials for trace level analysis of ibuprofen and clofibric acid in environmental and biological matrices, J. Chromatogr. A 1218 (2011) 6263-6270.

[14] F. Gonçalves, P. Correia, S.P. Silva, C. Almeida-Aguiar, Evaluation of antimicrobial properties of cork, FEMS Microbiol. Lett. 363 (2016) fnv231, https://doi.org/10.1093/femsle/fnv231.

[15] V.S. Ramachandran, Concrete admixtures handbook: properties, science, and technology, Noyes Publications (1995).

[16] J. Do, H. Song, H. So, Y. Soh, Antifungal effects of cement mortars with two types of organic antifungal agents, Cement Concrete Res. 35 (2005) 371-376.

[17] H. So, H. Jang, B. Lee, S. So, Antifungal performance of BFS mortar with various natural antifungal substances and their physical properties, Constr. Build. Mater. 108 (2016) 154-162, https://doi.org/10.1016/j.conbuildmat. 2015.12.022.
[18] CEN, EN 1015-11 - "Methods of test for masonry - Part 11: Determination of flexural and compressive strength of hardened mortar": EUROPEAN COMMITTEE FOR STANDARDIZATION (CEN), 1999.

[19] CEN, EN 1015-3 - "Methods of test for mortar for masonry - Part 3: Determination of consistence of fresh mortar (by flow table)": EUROPEAN COMMITTEE FOR STANDARDIZATION (CEN), 1999.

[20] A. Jerónimo, A. Camões, B. Aguiar, N. Lima, Hydraulic lime mortars with antifungal properties, Appl. Surface Sci. 483 (2019) 1192-1198.

[21] T. Dyer, Biodeterioration of Concrete, CRC Press, 2017.

[22] S. Ouhibi, C. Santos, R. Ghali, C. Soares, H. Abderrazek, R. Paterson, N. Lima, Penicillium tunisiense sp. nov., a novel species of Penicillium section Ramosa discovered from Tunisian orchard apples, Int. J. Syst. Evol. Micr. 68 (2018) 3217-3225, https://doi.org/10.1099/ijsem.0.002962.

[23] T. Ramos, A. Matos, J.S. Coutinho, Strength and durability of mortar using cork waste ash as cement replacement, Mater. Res. 17 (2014) 893-907, https://doi. org/10.1590/S1516-14392014005000092.

[24] A. Borges, I. Flores-Colen, J. Brito, Physical and mechanical performance of cement-based renders with different contents of fly ash, expanded cork granules and expanded clay, Constr. Build. Mater. 191 (2018) 535-543, https://doi.org/10.1016/j.conbuildmat.2018.10.043.

[25] Danuta Barnat-Hunek, Rafat Siddique, Grzegorz Lagod, Properties of hydrophobised lightweight mortars with expanded cork, Constr. Build. Mater. 155 (2017) 15-25, https://doi.org/10.1016/j.conbuildmat.2017.08.052.

[26] W. Zhao, J. Huang, Q. Su, T. Liu, Models for strength prediction of high-porosity cast-in-situ foamed concrete, Adv. Mater. Sci. Eng. 2 (2018) 1-10, https://doi. org/10.1155/2018/3897348.

[27] CEN, EN 998-1, Specification for mortar for mansonry - Part 1: Rendering and plastering mortar. Comite Europeen de Normalisation (CEN), 2010.

[28] S. Cunha, J.L. Aguiar, F. Pacheco-Torgal, Effect of temperature on mortars with incorporation of phase change materials, Constr. Build. Mater. 98 (2015) 89101, https://doi.org/10.1016/j.conbuildmat.2015.08.077.

[29] T. Verdier, M. Coutand, A. Bertron, C. Roques, A review of indoor microbial growth across building materials and sampling and analysis methods, Build Environ 80 (2014) 136-149, https://doi.org/10.1016/j.buildenv.2014.05.030.

[30] F.J.J. Segers, K.A. van Laarhoven, H.P. Huinink, O.C.G. Adan, H.A.B. Wösten, J. Dijksterhuis, The indoor fungus Cladosporium halotolerans survives humidity dynamics markedly better than Aspergillus niger and Penicillium rubens despite less growth at lowered steady-state water activity, Appl. Environ. Microb. 82 (2016) 5089-5098, https://doi.org/10.1128/AEM.00510-16.

[31] K. Loh, C. Gaylarde, M. Shirakawa, Photocatalytic activity of ZnO and $\mathrm{TiO} 2$ 'nanoparticles' for use in cement mixes, Constr. Build. Mater. 167 (2018) 853859, https://doi.org/10.1016/j.conbuildmat.2018.02.103.

[32] E. Stanaszek-Tomal, Influence of pore structure on humidity parameters of cement polymer mortars contaminated with filamentous fung, PLoS One 15 (2020), https://doi.org/10.1371/journal.pone.0231347.

[33] C.P. Hoang, K.A. Kinney, R.L. Corsi, P.J. Szaniszlo, Resistance of green building materials to fungal growth, Int. Biodeter. Biodegr. 64 (2010) 104-113, https:// doi.org/10.1016/j.ibiod.2009.11.001. 